\title{
Tepidibacter mesophilus sp. nov., a mesophilic fermentative anaerobe isolated from soil polluted by crude oil, and emended description of the genus Tepidibacter
}

Correspondence

Xu-Fen Zhu

xufenzhu@zju.edu.cn

\author{
Hai-Qin Tan, Xiao-Yue Wu, Xin-Qi Zhang, Min Wu and Xu-Fen Zhu \\ College of Life Sciences, Zhejiang University, Hangzhou 310058, PR China
}

The genus Tepidibacter was proposed by Slobodkin et al. (2003) with Tepidibacter thalassicus as the type species. Tepidibacter formicigenes was subsequently described by Urios et al. (2004). The two species were isolated from hydrothermal vents, and are thermophilic. Here we describe a novel fermentative, aerotolerant bacterium isolated from an oilfield as representing a third species of the genus. It was isolated from warm soil polluted by crude oil, and was mesophilic.

Strain $\mathrm{B} 1^{\mathrm{T}}$ was isolated from soil polluted by crude oil in the Karamay Oil Field $\left(45^{\circ} 36^{\prime} \mathrm{N} 84^{\circ} 57^{\prime} \mathrm{E}\right)$ in northwestern China in June 2009. For initial enrichment we used medium YC ( $\mathrm{pH} 7.0$ ), which contains (per litre distilled water) $20 \mathrm{~g} \mathrm{NaCl}, 0.9 \mathrm{~g} \mathrm{MgCl}_{2} .6 \mathrm{H}_{2} \mathrm{O}, 0.33 \mathrm{~g} \mathrm{KCl}, 1.4 \mathrm{~g}$ $\mathrm{MgSO}_{4} \cdot 7 \mathrm{H}_{2} \mathrm{O}, 0.14 \mathrm{~g} \mathrm{CaCl}_{2} \cdot 2 \mathrm{H}_{2} \mathrm{O}, 0.25 \mathrm{~g} \mathrm{NH}_{4} \mathrm{Cl}, 0.45 \mathrm{~g}$ $\mathrm{K}_{2} \mathrm{HPO}_{4}, 1 \mathrm{~g}$ yeast extract (Difco), $3 \mathrm{~g}$ Casamino acids, $1 \mathrm{ml}$ trace element solution SL-10 (Widdel et al., 1983), $0.4 \mathrm{~g}$ L-cysteine, $0.5 \mathrm{~g} \mathrm{Na}_{2} \mathrm{~S} .9 \mathrm{H}_{2} \mathrm{O}$ and $0.001 \mathrm{~g}$ resazurin.

The GenBank/EMBL/DDBJ accession number for the 16S rRNA gene sequence of strain $B 1^{\top}$ is $\mathrm{GQ} 231514$.

One supplementary figure is available with the online version of this paper.
Serum bottles $(50 \mathrm{ml})$ containing a liquid phase of $\mathrm{YC}$ medium under a gas phase of $\mathrm{O}_{2}$-free $\mathrm{N}_{2}$ were sealed and autoclaved for $20 \mathrm{~min}$ at $121{ }^{\circ} \mathrm{C}$. Bottles were anaerobically inoculated with approximately $2 \mathrm{~g}$ soil sample and incubated at $32{ }^{\circ} \mathrm{C}$ for 2 days. The Hungate roll-tube technique (Hungate, 1969; Bryant, 1972) was used to isolate strains from the turbid enrichment cultures. Strains were purified at least twice before being preserved in $25 \%$ glycerol at $-80{ }^{\circ} \mathrm{C}$. One of the isolates obtained, designated strain $\mathrm{B} 1^{\mathrm{T}}$, was phylogenetically affiliated with the genus Tepidibacter, showing 94.7 and $94.1 \% 16 \mathrm{~S}$ rRNA gene sequence similarity to the type strains of $T$. formicigenes and $T$. thalassicus, respectively. Strain $\mathrm{B}^{\mathrm{T}}$ also grew in aerobic medium.

DSMZ medium 985, in which the vitamin solution was replaced by $1 \mathrm{~g}$ yeast extract $1^{-1}$, was used as the basal medium for cultivation of strains $\mathrm{B}^{\mathrm{T}}$, T. formicigenes DSM $15518^{\mathrm{T}}$ and T. thalassicus DSM $15285^{\mathrm{T}}$. Unless stated otherwise, the medium was adjusted to $\mathrm{pH} 7.0$, before sterilization for $20 \mathrm{~min}$ at $121{ }^{\circ} \mathrm{C}$, and cultures were grown under a gas phase of $\mathrm{O}_{2}$-free $\mathrm{N}_{2}$. Cell morphology and motility were examined by optical microscopy (BX40; Olympus) and transmission electron microscopy (JEM-1230; JEOL) during the late-exponential or stationary growth phases. Colonies of 
strain $\mathrm{Bl}^{\mathrm{T}}$ were white and $0.2-0.5 \mathrm{~mm}$ in diameter after growing on modified medium 985 for $20 \mathrm{~h}$. Cells of strain $\mathrm{B}^{\mathrm{T}}$ were rods $(1.1-1.6 \times 2.3-4.7 \mu \mathrm{m})$ with peritrichous flagella. Round terminal endospores were also observed. Thin-section electron micrographs revealed a Gram-positive cell-wall structure and a lamellar structure in its endospores (Supplementary Fig. S1 available in IJSEM Online).

To determine the optimal conditions for growth, we incubated the isolate at $4,10,13,15,18,21,25,28,32,35,37$,
40 and $45{ }^{\circ} \mathrm{C}$. To test the $\mathrm{pH}$ range of growth, we adjusted the $\mathrm{pH}$ of the medium with the following buffers: MES ( $\mathrm{pH}$ 5.0-6.0), PIPES ( $\mathrm{pH}$ 6.5-7.0), Tricine ( $\mathrm{pH}$ 7.5-8.5) and CAPSO ( $\mathrm{pH} 9.0-10.0)$, at a concentration of $25 \mathrm{mM}$. To examine the effect of salt concentration on growth, different concentrations of $\mathrm{NaCl}$ or sea salts were added $[0-10 \%(\mathrm{w} / \mathrm{v})$, in increments of $0.5 \%]$. Strain $\mathrm{B}^{\mathrm{T}}$ showed optimal growth at $28-32{ }^{\circ} \mathrm{C}$ and $\mathrm{pH}$ 7.3. No growth was observed at 4 or $45{ }^{\circ} \mathrm{C}$ after incubation for 10 days. The $\mathrm{pH}$ range for growth was 6.0-8.9. Optimal growth was observed

Table 1. Differential phenotypic, physiological and genotypic characteristics between strain $B 1^{\top}$ and the type strains of recognized species of the genus Tepidibacter

Strains: $1, \mathrm{B1}^{\mathrm{T}}$; 2, T. formicigenes DSM $15518^{\mathrm{T}} ; 3$, T. thalassicus DSM $15285^{\mathrm{T}}$. Beef extract, peptone, tryptone, yeast extract, D-glucose, D-arabinose, cellulose, maltose and DL-alanine plus L-proline were used by all three strains. None of the strains used chitin, filter paper, olive oil, lactose, mannose, DL-alanine, L-glycine, acetate, betaine, butyrate, formate, fumarate, glycerol, lactate, methanol, D-sorbitol, succinate or urea. All strains were negative for the use of sodium thiosulfate, sodium sulfite, sodium sulfate, sodium nitrite, sodium nitrate and $\mathrm{FeCl}_{3}$ as electron acceptors. Oxidase and catalase activity were negative for all strains.

\begin{tabular}{|c|c|c|c|}
\hline Characteristic & 1 & 2 & 3 \\
\hline \multicolumn{4}{|l|}{ Growth } \\
\hline Optimum temperature $\left({ }^{\circ} \mathrm{C}\right)$ & $28-32$ & 45 & 50 \\
\hline Temperature range $\left({ }^{\circ} \mathrm{C}\right)$ & $10-40$ & $25-55$ & $28-60$ \\
\hline Optimum pH & 7.3 & $6.5-6.8$ & $6.5-7.0$ \\
\hline $\mathrm{pH}$ range & $6.0-8.9$ & $5.0-8.5$ & $5.0-8.5$ \\
\hline $\begin{array}{l}\text { Optimum } \mathrm{NaCl} \\
\text { concentration }(\%, \mathrm{w} / \mathrm{v})\end{array}$ & 0.5 & 2 & 2 \\
\hline $\begin{array}{l}\text { Optimum sea salts } \\
\text { concentration }(\%, w / v)\end{array}$ & 1 & 3 & 2.5 \\
\hline $\mathrm{S}^{0}$ as electron acceptor & + & - & + \\
\hline \multicolumn{4}{|l|}{ Utilization of: } \\
\hline Albumin & - & - & + \\
\hline Casein & + & - & + \\
\hline Gelatin & - & $+^{*}$ & - \\
\hline Starch & + & $+^{*}$ & + \\
\hline D-Fructose & + & - & - \\
\hline D-Galactose & + & - & - \\
\hline D-Ribose & + & - & - \\
\hline L-Rhamnose & + & - & - \\
\hline Sucrose & - & + & - \\
\hline Trehalose & + & - & - \\
\hline D-Xylose & + & - & - \\
\hline L-Arginine & - & - & + \\
\hline L-Valine & + & + & $-\dagger$ \\
\hline DL-Alanine + L-glycine & + & + & $+\ddagger$ \\
\hline D-Mannitol & - & + & - \\
\hline Ethanol & - & + & - \\
\hline Pyruvate & - & + & + \\
\hline $\begin{array}{l}\text { Fermentation products from } \\
\text { glucose }\end{array}$ & Acetate, ethanol & Formate, acetate, ethanol & Ethanol, acetate, $\mathrm{H}_{2}, \mathrm{CO}_{2}$ \\
\hline DNA G $+C$ content $(\mathrm{mol} \%)$ & 29.8 & 28.3 & 24.9 \\
\hline
\end{tabular}

${ }^{\star}$ Urios et al. (2004) reported a negative reaction.

$\dagger$ Slobodkin et al. (2003) reported a positive reaction.

$\ddagger$ Slobodkin et al. (2003) reported a negative reaction. 
in the presence of $0.5-1 \% \mathrm{NaCl}(\mathrm{w} / \mathrm{v})$. No growth occurred with $9.5 \% \mathrm{NaCl}$ or sea salts. Under optimal growth conditions, the generation time of strain $\mathrm{B} 1^{\mathrm{T}}$ was $1.2 \mathrm{~h}$.

Assimilation of carbon sources was tested under a gas phase of $\mathrm{O}_{2}$-free $\mathrm{N}_{2}$, by using the basal salts of the modified medium 985, supplemented with $0.01 \%$ yeast extract (BD). Complex proteinaceous substrates $\left(10 \mathrm{~g} \mathrm{l}^{-1}\right)$ such as tryptone $(\mathrm{BD})$, yeast extract, casein $(\mathrm{BD})$, peptone $(\mathrm{BD})$ and beef extract, polysaccharides $\left(10 \mathrm{~g} \mathrm{l}^{-1}\right)$ such as filter paper, chitin and starch, and organic acids $(20 \mathrm{mM})$, olive oil $\left(10 \mathrm{~g} \mathrm{l}^{-1}\right)$, methanol $(20 \mathrm{mM})$, ethanol $(20 \mathrm{mM})$, glycerol $(25 \mathrm{mM})$, sorbitol $(25 \mathrm{mM})$, glycine betaine $(5 \mathrm{mM})$ and urea $(0.5 \%)$ were autoclaved for $20 \mathrm{~min}$ at $121{ }^{\circ} \mathrm{C}$. Sugars (added at a concentration of $20 \mathrm{mM}$ ), amino acids (20 mM) and albumin $\left(10 \mathrm{~g} \mathrm{l}^{-1}\right)$ were sterilized under UV light. All tests were performed in triplicate. To analyse the use of accessory electron acceptors, elemental sulfur $\left(150 \mathrm{meq} \mathrm{l}^{-1}\right)$, sodium thiosulfate $(20 \mathrm{mM})$, sodium sulfite $(5 \mathrm{mM})$, sodium sulfate $(20 \mathrm{mM})$, sodium nitrite $(5 \mathrm{mM})$, sodium nitrate $(20 \mathrm{mM})$ or $\mathrm{FeCl}_{3}(20 \mathrm{mM})$ was added from autoclaved stock solutions to medium YC (lacking the reductant $\mathrm{Na}_{2} \mathrm{~S}$, L-cysteine and Casamino acids). Oxygen was removed as described by Grishchenkov et al. (2000). Reduction of the electron acceptors was tested by using the method described by Ogg \& Patel (2009). Production of $\mathrm{H}_{2} \mathrm{~S}$ was tested in sulfate-free medium by using lead acetate paper, as indicated by Alain et al. (2002). The results of these phenotypic tests are given in Table 1 and in the species description below.

Fatty acid methyl esters were obtained from freeze-dried cells of strain $\mathrm{B}^{\mathrm{T}}$ and from the type strains of $T$. formicigenes and T. thalassicus as described by Kuykendall et al. (1988). The identification and quantification of the fatty acid methyl esters as well as the numerical analysis of the fatty acid profiles were examined as described by Zhang et al. (2010), matching the results with the ANAEROBE BHIBLA 3.80 library. The results are presented in Table 2 . The major fatty acid in the three strains was iso- $\mathrm{C}_{15: 0}$, but its content was somewhat lower in strain $\mathrm{B}^{\mathrm{T}}$ than in the two reference strains, while the content of $\mathrm{C}_{14: 0}, \mathrm{C}_{16: 0}$, iso$\mathrm{C}_{13: 0}$ and $\mathrm{C}_{16: 1}$ cis9 was significantly higher in strain $\mathrm{B1}^{\mathrm{T}}$ than in the two other strains. Moreover, $\mathrm{C}_{12: 0}, \mathrm{C}_{15: 0}$ and $\mathrm{C}_{16: 1}$ cis7 were found in strain $\mathrm{B}^{\mathrm{T}}$ but not in T. thalassicus DSM $15285^{\mathrm{T}}$ or $T$. formicigenes DSM $15518^{\mathrm{T}}$.

Genomic DNA was extracted and purified by using the method described by Marmur (1961). The 16S rRNA gene was amplified by PCR by using universal bacterial primers $27 \mathrm{~F}$ and $1492 \mathrm{R}$. Sequence similarity analysis and multiple sequence alignment were performed with the EzTaxon service (Chun et al., 2007) and CLUSTAL w 1.8 (Thompson et al., 1994), respectively. Phylogenetic trees were reconstructed by the neighbour-joining (Saitou \& Nei, 1987) and maximum-parsimony methods (Fitch, 1971) with the MEGA4 program package (Tamura et al., 2007). Evolutionary distances were calculated according to the algorithm of the Kimura two-parameter model (Kimura, 1980) for the
Table 2. Fatty acid profiles of strain $B 1^{\top}$ and recognized members of the genus Tepidibacter

Strains: $1, \mathrm{B1}^{\mathrm{T}} ; 2$, T. formicigenes DSM $15518^{\mathrm{T}} ; 3$, T. thalassicus DSM $15285^{\mathrm{T}}$. Values are percentages of the total fatty acids. - , Not detected.

\begin{tabular}{|lrcc|}
\hline Fatty acid & $\mathbf{1}$ & $\mathbf{2}$ & $\mathbf{3}$ \\
\hline Unbranched saturated & & & \\
$\mathrm{C}_{14: 0}$ & 20.9 & 2.4 & - \\
$\mathrm{C}_{16: 0}$ & 9.3 & 5.7 & - \\
$\mathrm{C}_{18: 0}$ & 1.9 & 3.1 & 2.2 \\
$\mathrm{C}_{12: 0}$ & 0.5 & - & - \\
$\mathrm{C}_{15: 0}$ & 0.4 & - & - \\
Branched saturated & & & \\
iso- $\mathrm{C}_{15: 0}$ & 51.8 & 77.7 & 97.0 \\
iso- $\mathrm{C}_{13: 0}$ & 4.0 & 1.9 & - \\
anteiso-C & & \\
iso- $\mathrm{C}_{17}: 0$ & 1.5 & 4.0 & - \\
iso- $\mathrm{C}_{14: 0}$ & 1.2 & 1.0 & - \\
Unsaturated & 0.6 & 0.7 & 0.8 \\
$\mathrm{C}_{16: 1}$ cis9 & & & \\
$\mathrm{C}_{16: 1}$ cis7 & 6.6 & 2.1 & - \\
$\mathrm{C}_{18: 1}$ cis9 & 0.7 & - & - \\
\hline
\end{tabular}

neighbour-joining method. Consequently, the almost-complete $16 \mathrm{~S}$ rRNA gene sequence (1438 nt) was obtained for strain $\mathrm{B1}^{\mathrm{T}}$. Phylogenetic analysis based on $16 \mathrm{~S}$ rRNA gene sequences indicated that the new isolate clustered with the two recognized members of the genus Tepidibacter (Fig. 1).

The DNA $\mathrm{G}+\mathrm{C}$ content was determined by HPLC, as described by Mesbah et al. (1989), with Escherichia coli K12 DNA as the calibration standard. The genomic DNA $\mathrm{G}+\mathrm{C}$ content of strain $\mathrm{B}^{\mathrm{T}}$ was $29.8 \mathrm{~mol} \%$.

Based on the phenotypic and genotypic characteristics described above, differences between strain $\mathrm{B}^{\mathrm{T}}$ and the type strains of the two related species of the genus Tepidibacter were evident. Strain $\mathrm{B1}^{\mathrm{T}}$ utilized proteinaceous substrates and trace amounts of amino acids, but also some sugars such as D-fructose, D-galactose, D-ribose, trehalose, L-rhamnose and D-xylose (Table 1). It was able to assimilate more and different carbon sources than the recognized species of the genus Tepidibacter. Moreover, strain $\mathrm{B} 1^{\mathrm{T}}$ was mesophilic, being able to grow at $10-40{ }^{\circ} \mathrm{C}$ (optimally at $28-32{ }^{\circ} \mathrm{C}$ ), while the two recognized species of the genus Tepidibacter were moderately thermophilic with optimal growth at 45 and $50{ }^{\circ} \mathrm{C}$. Table 1 shows additional differences, such as the requirement for $\mathrm{NaCl}$ or sea salts for growth, and the main products of glucose fermentation. The major distinguishing chemotaxonomic characteristics were relatively larger amounts of $\mathrm{C}_{14: 0}, \mathrm{C}_{16: 0}$, iso- $\mathrm{C}_{13: 0}, \mathrm{C}_{16: 1}$ cis9 and iso- $\mathrm{C}_{15: 0}$, and a lower level of iso- $\mathrm{C}_{15: 0}$ in strain $\mathrm{B} 1^{\mathrm{T}}$.

On the basis of data from the present polyphasic taxonomic characterization, we suggest that strain $B 1^{\mathrm{T}}$ represents a novel species of the genus Tepidibacter, for which the name Tepidibacter mesophilus sp. nov. is proposed. 


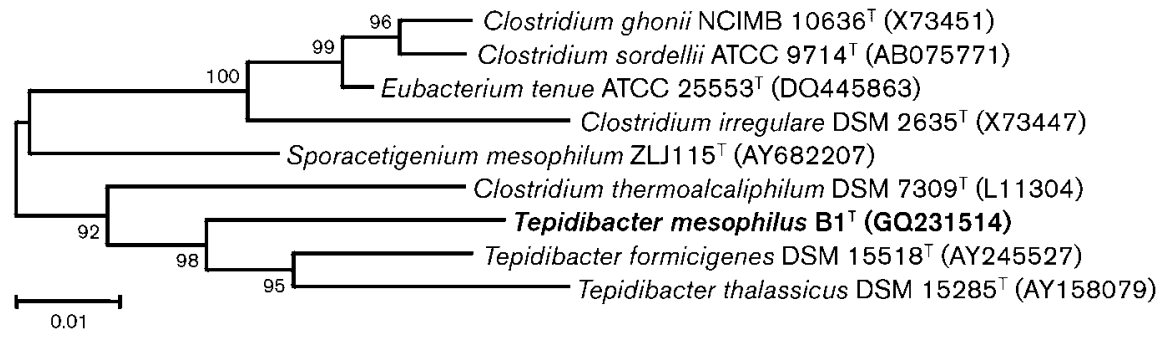

Fig. 1. Neighbour-joining phylogenetic tree based on $16 \mathrm{~S}$ rRNA gene sequences, showing the relationships between strain $\mathrm{B} 1^{\top}$ and related taxa. Numbers at nodes are bootstrap values based on 1000 replicates. Bar, 1 substitution per $100 \mathrm{nt}$ positions.

\section{Emended description of the genus Tepidibacter}

Anaerobic or aerotolerant, and moderately thermophilic or mesophilic. Other properties are as given by Slobodkin et al. (2003).

\section{Description of Tepidibacter mesophilus sp. nov.}

Tepidibacter mesophilus [me.so.phi'lus. Gr. adj. mesos middle; Gr. adj. philos loving; N.L. masc. adj. mesophilus middle (temperature)-loving, mesophilic].

Cells are Gram-positive, aerotolerant, rod-shaped (1.1$1.6 \times 2.3-4.7 \mu \mathrm{m})$ and motile by means of peritrichous flagella. Terminal spores are observed. Colonies are white, circular and convex with entire margins. Optimal growth occurs at $28-32{ }^{\circ} \mathrm{C}$ and $\mathrm{pH} 7.3$. Growth occurs at $10-40{ }^{\circ} \mathrm{C}$ and $\mathrm{pH}$ 6.0-8.9. Grows in the presence of $0-9.0 \%(\mathrm{w} / \mathrm{v})$ (optimally at $0.5-1 \%$ ) $\mathrm{NaCl}$ or sea salts. Oxidase- and catalase-negative. $\mathrm{H}_{2} \mathrm{~S}$ is produced from cysteine or proteinaceous substrates. Utilizes beef extract, casein, peptone, tryptone, yeast extract, D-glucose, D-fructose, Dgalactose, maltose, L-rhamnose, D-ribose, starch, trehalose, xylose, L-valine, DL-alanine plus L-proline and DL-alanine plus L-glycine, but not chitin, filter paper, olive oil, Larabinose, cellulose, D-lactose, mannose, D-sorbitol, acetate, DL-alanine, L-glycine, betaine, butyrate, formate, fumarate, glycerol, lactate, methanol, succinate or urea. The main products of glucose fermentation are ethanol and acetate. Elemental sulfur is reduced to hydrogen sulfide. Sodium thiosulfate, sodium sulfite, sodium sulfate, sodium nitrite, sodium nitrate and $\mathrm{FeCl}_{3}$ are not used as electron acceptors. The major cellular fatty acids are iso- $\mathrm{C}_{15: 0}$, iso$\mathrm{C}_{14: 0}, \mathrm{C}_{16: 0}$ and iso- $\mathrm{C}_{13: 0}$. The DNA G+C content of the type strain is $29.8 \mathrm{~mol} \%$.

The type strain, $\mathrm{B}^{\mathrm{T}}$ (=CGMCC $\left.1.5148^{\mathrm{T}}=\mathrm{JCM} 16806^{\mathrm{T}}\right)$, was isolated from an oil-polluted soil of the Karamay Oil Field in north-western China.

\section{Acknowledgements}

We thank Professor Aharon Oren (The Hebrew University of Jerusalem, Israel) for his valuable suggestions and critical proofreading of the manuscript. This work was supported by grants from the
National Natural Science Foundation of China (grant no. 30970002) and from the National Science and Technology Major Projects - water pollution control and treatment project (2008ZX07101-006-3).

\section{References}

Alain, K., Pignet, P., Zbinden, M., Quillevere, M., Duchiron, F., Donval, J. P., Lesongeur, F., Raguenes, G., Crassous, P. \& other authors (2002). Caminicella sporogenes gen. nov., sp. nov., a novel thermophilic spore-forming bacterium isolated from an East-Pacific Rise hydrothermal vent. Int J Syst Evol Microbiol 52, 1621-1628.

Bryant, M. P. (1972). Commentary on the Hungate technique for culture of anaerobic bacteria. Am J Clin Nutr 25, 1324-1328.

Chun, J., Lee, J. H., Jung, Y., Kim, M., Kim, S., Kim, B. K. \& Lim, Y. W. (2007). EzTaxon: a web-based tool for the identification of prokaryotes based on $16 \mathrm{~S}$ ribosomal RNA gene sequences. Int J Syst Evol Microbiol 57, 2259-2261.

Fitch, W. M. (1971). Toward defining the course of evolution: minimum change for a specific tree topology. Syst Zool 20, 406-416.

Grishchenkov, V. G., Townsend, R. T., McDonald, T. J., Autenrieth, R. L., Bonner, J. S. \& Boronin, A. M. (2000). Degradation of petroleum hydrocarbons by facultative anaerobic bacteria under aerobic and anaerobic conditions. Process Biochem 35, 889-896.

Hungate, R. E. (1969). A roll tube method for cultivation of strict anaerobes. In Methods in Microbiology, vol. 3B, pp. 117-132. Edited by J. R. Norris \& R. W. Ribbons. London: Academic Press.

Kimura, M. (1980). A simple method for estimating evolutionary rates of base substitutions through comparative studies of nucleotide sequences. J Mol Evol 16, 111-120.

Kuykendall, L. D., Roy, M. A., O’Neill, J. J. \& Devine, T. E. (1988). Fatty acids, antibiotic resistance, and deoxyribonucleic acid homology groups of Bradyrhizobium japonicum. Int J Syst Bacteriol 38, 358-361.

Marmur, J. (1961). A procedure for the isolation of deoxyribonucleic acid from microorganisms. J Mol Biol 3, 208-218.

Mesbah, M., Premachandran, U. \& Whitman, W. B. (1989). Precise measurement of the $\mathrm{G}+\mathrm{C}$ content of deoxyribonucleic acid by highperformance liquid chromatography. Int J Syst Bacteriol 39, 159-167.

Ogg, C. D. \& Patel, B. K. C. (2009). Thermotalea metallivorans gen. nov., sp. nov., a thermophilic, anaerobic bacterium from the Great Artesian Basin of Australia aquifer. Int J Syst Evol Microbiol 59, 964-971.

Saitou, N. \& Nei, M. (1987). The neighbor-joining method: a new method for reconstructing phylogenetic trees. Mol Biol Evol 4, 406425.

Slobodkin, A. I., Tourova, T. P., Kostrikina, N. A., Chernyh, N. A., Bonch-Osmolovskaya, E. A., Jeanthon, C. \& Jones, B. E. (2003). 
Tepidibacter thalassicus gen. nov., sp. nov., a novel moderately thermophilic, anaerobic, fermentative bacterium from a deep-sea hydrothermal vent. Int J Syst Evol Microbiol 53, 1131-1134.

Tamura, K., Dudley, J., Nei, M. \& Kumar, S. (2007). MEGA4: molecular evolutionary genetics analysis (MEGA) software version 4.0. Mol Biol Evol 24, 1596-1599.

Thompson, J. D., Higgins, D. G. \& Gibson, T. J. (1994). CluSTAL W: improving the sensitivity of progressive multiple sequence alignment through sequence weighting, position-specific gap penalties and weight matrix choice. Nucleic Acids Res 22, 4673-4680.
Urios, L., Cueff, V., Pignet, P. \& Barbier, G. (2004). Tepidibacter formicigenes sp. nov., a novel spore-forming bacterium isolated from a Mid-Atlantic Ridge hydrothermal vent. Int J Syst Evol Microbiol 54, 439-443.

Widdel, F., Kohring, G. W. \& Mayer, F. (1983). Studies on dissimilatory sulfate-reducing bacteria that decompose fatty acids. Arch Microbiol 134, 286-294.

Zhang, X. Q., Ying, Y., Ye, Y., Xu, X. W., Zhu, X. F. \& Wu, M. (2010). Thermus arciformis sp. nov., a thermophilic species from a geothermal area. Int J Syst Evol Microbiol 60, 834-839. 